\title{
Trends and characteristics of oral and maxillofacial injuries in Nigeria: a review of the literature Wasiu Lanre Adeyemo* ${ }^{* 1}$, Akinola Ladipo Ladeinde ${ }^{\dagger 2}$, Mobolanle Olugbemiga Ogunlewe ${ }^{\dagger 2}$ and Olutayo James ${ }^{\dagger 1}$
}

\author{
Address: ${ }^{1}$ Department of Oral and Maxillofacial Surgery, Lagos University Teaching Hospital, P.M.B. 12003, Lagos, Nigeria and ${ }^{2}$ Department of \\ Oral and Maxillofacial Surgery, College of Medicine, University of Lagos, P.M.B. 12003, Lagos, Nigeria \\ Email: Wasiu Lanre Adeyemo* - lanreadeyemo@yahoo.com; Akinola Ladipo Ladeinde - drakinladeinde@yahoo.com; \\ Mobolanle Olugbemiga Ogunlewe - gbemilewe@yahoo.co.uk; Olutayo James - olutayojames@yahoo.com \\ * Corresponding author †Equal contributors
}

Published: 04 October 2005

Head \& Face Medicine 2005, I:7 doi:10.1 186/1746-160X-1-7

This article is available from: http://www.head-face-med.com/content/I/I/7

(c) 2005 Adeyemo et al; licensee BioMed Central Ltd.

This is an Open Access article distributed under the terms of the Creative Commons Attribution License (http://creativecommons.org/licenses/by/2.0), which permits unrestricted use, distribution, and reproduction in any medium, provided the original work is properly cited.
Received: 09 June 2005

Accepted: 04 October 2005

\begin{abstract}
Background: The etiology of maxillofacial injuries varies from one country to another and even within the same country depending on the prevailing socioeconomic, cultural and environmental factors. Periodic verification of the etiology of maxillofacial injuries helps to recommend ways in which maxillofacial injuries can be averted. The aim of the present study is therefore to analyse the characteristics and trends of maxillofacial injuries in Nigeria based on a systematic review of the literature.
\end{abstract}

Methods: A literature search using MEDLINE was conducted for publications on maxillofacial injuries in Nigeria. The relevant references in these publications were manually searched for additional non-Medline articles or abstracts. Forty-two studies met the inclusion criteria and the full-texts of these articles were thoroughly examined. Due to lack of uniformity and consistency in assessment and measurement variables, and treatment modalities in most of the studies, it was impossible to apply the traditional methods of a systematic review. Therefore, a narrative approach was conducted to report the findings of the included studies.

Results: Although, other causes like assaults, sport injuries, and industrial accidents increased in numbers, throughout the period between 1965 and 2003, road traffic crashes remained the major etiological factor of maxillofacial injuries in all regions, except northeastern region where assault was the major cause. A significant increase in motorcycles related maxillofacial injuries was observed in most urban and suburban centres of the country. Animal attacks were not an unusual cause of maxillofacial injuries in most parts of northern Nigeria. Patients in the age group of 2I-30 years were mostly involved. A strong tendency toward an equal male-to-female ratio was observed between earlier and later periods.

Conclusion: Road traffic crashes remain the major cause of maxillofacial injuries in Nigeria, unlike in most developed countries where assaults/interpersonal violence has replaced road traffic crashes as the major cause of the injuries. There is a need to reinforce legislation aimed to prevent road traffic crashes and the total enforcement of existing laws to reduce maxillofacial injuries among children and adults. Special attention should also be paid by the authority to improve the socioeconomic conditions of Nigerian populace. 


\section{Background}

Skeletal and soft tissue injuries of the face constitute quite a significant portion of the workload of the oral and maxillofacial surgeons in Nigeria [1]. Being the most exposed part of the body, the face is particularly vulnerable to such injuries, $20-60 \%$ of all those involved in automobile accidents having some level of facial fractures [2,3]. Surveys of facial injuries have shown that the etiology varies from one country to another and even within the same country depending on the prevailing socioeconomic, cultural and environmental factors [4-6]. Earlier studies from Europe and America revealed that road traffic crashes (RTC) were the most frequent cause of facial injuries $[7,8]$. However, more recent studies have shown that assault is now the most common cause of maxillofacial injuries in developed countries [9-11], whereas traffic accidents remain the most frequent cause in many developing countries [12-19].

Periodic verification of the etiology of maxillofacial injuries helps to assess the proficiency of road safety measures such as speed limit, drunk driving, and seat beat belt laws and the behavioural patterns of the people in different countries and helps to recommend other ways in which injuries to the face can be averted [20].

The aim of the present study is therefore to analyse the characteristics and trends of maxillofacial injuries in Nigeria based on a systematic review of the literature.

\section{Methods}

A computerized literature search using MEDLINE was conducted for publications on maxillofacial injuries in Nigeria published between 1970 and 2005. For this search, the medical subject headings "maxillofacial injuries" or "maxillofacial fractures" or "mandible fractures" or "middle-third fractures" or "facial fractures" or "zygoma fractures" were combined with "Nigeria" or "Africa". The Boolean operator 'AND' was used to combine and narrow the searches. We manually searched the references in these articles to look for additional relevant non-Medline articles or abstracts. The full-texts of all these articles were thoroughly examined. Personal contacts were also made with institutions and investigators of previous studies for missing data and also for the provision of articles found suitable for the review, but not readily available to us. One author (WLA) conducted the literature search. All the authors agreed upon inclusion and exclusion criteria.

\section{Inclusion criteria}

1. Availability of the full-text article

2. Retrospective or prospective studies

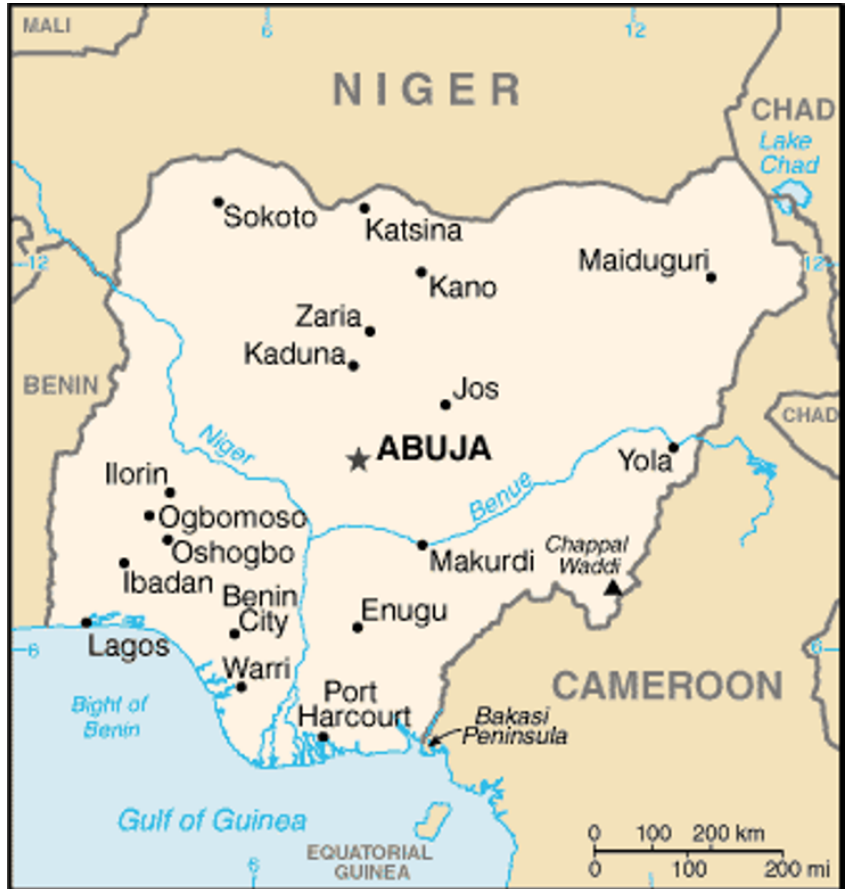

Figure I

Map of Nigeria (source: CIA's The World Factbook). Ife (not shown) lies in the north east of Ibadan below Oshogbo.

\section{All age groups (Children and adults)}

\section{Civilian-type injuries}

Publications on maxillofacial injuries sustained during Nigerian civil war were excluded from the review.

\section{Assessment of the studies}

A total of 44 full-text articles and abstracts were identified. Two articles on maxillofacial injuries sustained during the Nigerian civil war were excluded. A total of 42 publications published between January 1977 and April 2005, which satisfied the inclusion criteria were, therefore included in the review. These included 34 Medline and 8 non-Medline articles. These publications were based on patients seen and treated between 1965 and 2003 from different centers of the six geopolitical zones of the country (Figure 1) including: Ibadan, south west (SW) [18,19,21-35], Lagos (SW) [36-40], Ife (SW) [1,41-46], Kaduna, north central (NC) [47-50], Sokoto, north west (NW) [51,52], Maiduguri, north east (NE) $[4,53,54]$, Enugu, south east (SE) $[15,16,55]$, and Benin city, south south (SS) [56] (Table 1). 
Table I: Location of investigations, aetiology of injury and gender distribution.

\begin{tabular}{|c|c|c|c|c|c|c|}
\hline Author (Ref.-No.) & Location $^{\mathrm{a}}$ & $\begin{array}{l}\text { Major cause of } \\
\text { injury }\end{array}$ & $\begin{array}{l}2^{\text {nd }} \text { major cause of } \\
\text { injury }\end{array}$ & $\begin{array}{l}\% \text { motorcycle } \\
\text { related }\end{array}$ & $\begin{array}{l}\text { Male/female } \\
\text { ratio (\%) }\end{array}$ & Tissue affected \\
\hline Ajagbe et al. (2I) & Ibadan (SW) & RTC (63) & Falls (19) & 10 & $2.1: 1$ & Hard Tissue \\
\hline Nwoku et al. (36) & Lagos (SW) & RTC & \#\# & \#\#\# & $3: 1$ & Hard/Soft Tissues \\
\hline Ajagbe et al. (34) & Ibadan (SW) & RTC & Falls & 15.7 & $3: 1$ & Hard Tissue \\
\hline Adekeye (47) & Kaduna (NC) & RTC (76) & Assaults (13) & 22 & $16.9: 1$ & Hard/Soft Tissues \\
\hline Adekeye (48) & Kaduna (NC) & RTC (82) & Falls & \#\#\# & $24: 1$ & Hard Tissue \\
\hline Adekeye (49) & Kaduna (NC) & RTC & \#\# & \#\#\# & $2: 1$ & Hard Tissue \\
\hline Nyako (23) & Ibadan (SW) & RTC (77) & Assaults (9) & 10.6 & $6.4: 1$ & Hard Tissue \\
\hline Odusanya (4I) & Ife $(S W)$ & RTC (53) & Falls & 22.1 & $5.4: 1$ & Hard Tissue \\
\hline Abiose (22) & Ibadan (SW) & RTC (8I) & Assaults (9) & \#\#\# & $5.5: 1$ & Hard Tissue \\
\hline Akinwande (37) & Lagos (SW) & RTC (65) & Assaults (12) & 18.5 & $4.2: 1$ & Hard/Soft Tissues \\
\hline Abiose (32) & lbadan (SW) & RTC (8I) & Assaults (7) & \#\#\# & $\mid 4: 1$ & Hard Tissue \\
\hline Arotiba (38) & Lagos (SW) & $\operatorname{RTC}(100)$ & \# & 6.3 & 2.3:1 & Hard Tissue \\
\hline Arotiba (39) & Lagos (SW) & $\operatorname{RTC}(63)$ & Assaults (20) & 4 & $2.1: 1$ & Hard Tissue \\
\hline Oji (I5) & Enugu (SE) & RTC (83) & Assaults (8) & 21 & $3: 1$ & Hard Tissue \\
\hline Ogunbodede (52) & Sokoto (NW) & 'Camel bite & $\#$ & \# & $\#$ & Hard/Soft Tissues \\
\hline Denloye et al. (33) & Ibadan (SW) & RTC (47) & Falls (4I) & \#\#\# & I.8:1 & Hard/Soft Tissues \\
\hline Ugboko et al. (I) & Ife $(S W)$ & RTC (72) & Falls (II) & 14.5 & 4.1:1 & Hard/Soft Tissues \\
\hline Akinwande et al. (40) & Lagos (SW) & bGunshots (100) & $\#$ & $\#$ & $5.1: 1$ & Hard/Soft Tissues \\
\hline Oji (55) & Enugu (SE) & RTC (28) & Assaults (25) & 5 & 2.6:1 & Hard Tissue \\
\hline Ugboko et al. (46) & Ife (SW) & RTC (50) & Falls (3I) & 1.9 & $6.4: 1$ & Hard/Soft Tissues \\
\hline Oji (16) & Enugu (SE) & RTC (83) & Assaults (8) & 21 & $3: 1$ & Hard Tissue \\
\hline Olasoji (53) & Maiduguri (NE) & bAssaults $(100)$ & \# & \# & $2.5: 1$ & Hard/Soft Tissues \\
\hline Ugboko et al. (42) & Ife (SW) & 'Gunshots (100) & \# & \# & $21: 1$ & Hard /Soft Tissues \\
\hline Fasola et al. (28) & Ibadan (SW) & bSports (100) & \# & \# & 4.1:1 & Hard Tissue \\
\hline Fasola et al. (30) & lbadan (SW) & RTC (38) & Falls (25) & \#\#\# & $2.6: 1$ & Soft Tissue \\
\hline Fasola et al. (19) & Ibadan (SW) & RTC (79) & Assaults (9) & \#\# & $7.6: 1$ & Hard/Soft Tissues \\
\hline Fasola et al. (25) & Ibadan (SW) & RTC (52) & Falls (24) & 3.2 & 2.6:1 & Hard/Soft Tissues \\
\hline Fasola et al. (26) & Ibadan (SW) & RTC (53) & Falls (24) & \#\#\# & 2.8:1 & Hard Tissue \\
\hline Olasoji et al. (4) & Maiduguri (NE) & Assaults (48) & RTC (36) & 9 & $2.2: 1$ & Hard /Soft Tissues \\
\hline Olasoji et al. (54) & Maiduguri (NE) & RTC (54) & Falls (25) & 2 & 7.5:1 & Hard/Soft Tissues \\
\hline Ugboko et al. (5I) & North (NE, NW, NC) & bAnimal attacks & \# & \# & $4: 1$ & Hard/Soft Tissues \\
\hline Oginni et al. (43) & Ife (SW) & bDog bites & \# & \# & $5: 3$ & Soft Tissue \\
\hline Oginni et al. (44) & Ife (SW) & Falls (38) & RTC (33) & \# & I.4:1 & Soft Tissue \\
\hline Fasola et al. (29) & Ibadan (SW) & RTC (76) & Assaults (9) & \#\# & 2.7:1 & Hard/Soft Tissues \\
\hline Fasola et al. (3I) & Ibadan (SW) & RTC (82) & Sports (8) & \#\#\# & $5.3: 1$ & Hard Tissue \\
\hline Fasola et al. (18) & lbadan (SW) & RTC (69) & Assaults (12) & 20.6 & $3.3: 1$ & Hard Tissue \\
\hline Fasola et al. (24) & Ibadan (SW) & RTC (69) & $\#$ & 15.1 & 2.9:1 & Hard Tissue \\
\hline Fasola et al. (27) & Ibadan (SW) & RTC (59) & Falls $(2 I)$ & 1.9 & I:I & Hard Tissue \\
\hline Saheeb et al. (56) & Benin (SS) & RTC (66) & Assaults (10) & 26.5 & 2.7:1 & Hard /Soft Tissues \\
\hline Adebayo et al. (50) & Kaduna (NC) & RTC (56) & Falls (24) & \#\# & 4.7:1 & Hard Tissue \\
\hline Bankole et al. (35) & Ibadan (SW) & Falls (66) & RTC (18) & \#\#\# & 2.3:1 & Soft Tissue \\
\hline Ugboko et al. (45) & Ife (SW) & RTC (74) & Falls/Assaults (14) & 9.4 & $6: 1$ & Hard Tissue \\
\hline
\end{tabular}

a(SW) South-west, (SE) South-east (SS) South-south, (NW) North-west, (NE) North-east, (NC) North-central

bPublications on a single specific etiology

RTC = road traffic crash

\# = not applicable

\#\# not specified

\#\#\# not separately classified

A protocol was prepared to identify the following features of each study: type of participants (i.e. adults or children or both groups), number of injuries analyzed, etiology of injury, peak age of incidence, gender predilection, site of injury, target population, as well as period and location of the study (Table 1, 2). Treatment modalities were also assessed. 
Table 2: Type of included study, number of patients analyzed, target population and peak age of incidence.

\begin{tabular}{|c|c|c|c|c|c|}
\hline Author (Ref.-No.) & Type of study & $\mathrm{n}$ of patients & Target population & $\begin{array}{l}\text { Bone mostly affected } \\
\text { (\%) }\end{array}$ & $\begin{array}{l}\text { Peak age of incidence, } \\
\text { years }(\%)\end{array}$ \\
\hline Ajagbe et al (2I) & retrospective & 203 & total & mandible (60.5) & $21-30(32)$ \\
\hline Nwoku et al (36) & retrospective & 84 & total & mandible (90) & \#\# \\
\hline Ajagbe et al (34) & retrospective & 324 & total & mandible (60) & $21-30$ \\
\hline Adekeye (47) & prospective & 1447 & total & mandible (62.5) & $21-30(56)$ \\
\hline Adekeye (48) & retrospective & 337 & total & $\#$ & $21-40(80)$ \\
\hline Adekeye (49) & retrospective & 85 & Children & mandible & $>10$ \\
\hline Nyako (23) & retrospective & 341 & total & mandible (73) & $21-30(46)$ \\
\hline Odusanya (4I) & retrospective & 231 & total & mandible (67) & $21-30$ \\
\hline Abiose (22) & retrospective & 104 & total & mandible (75) & $21-30(43)$ \\
\hline Akinwande (37) & prospective & 208 & total & mandible & $2 \mathrm{I}-30(5 \mathrm{I})$ \\
\hline Abiose (32) & retrospective & 59 & total & $\#$ & $21-30$ \\
\hline Arotiba (38) & prospective & 128 & total & mandible (62) & $20-29(>40)$ \\
\hline Arotiba (39) & prospective & 202 & total & mandible (64) & $20-29(40)$ \\
\hline Oji (I5) & retrospective & 900 & total & mandible (42) & $21-30(36)$ \\
\hline Ogunbodede (52) & case report & 1 & $\#$ & $\#$ & $\#$ \\
\hline Denloye et al (33) & retrospective & 106 & Children & mandible & $0-8(62)$ \\
\hline Ugboko et al (I) & retrospective & 442 & total & mandible (64) & $21-30(39)$ \\
\hline Akinwande et al (40) & prospective & 35 & total & mandible & $20-34(66)$ \\
\hline Oji (55) & retrospective & 40 & Children & mandible (89) & $9-11(40)$ \\
\hline Ugboko et al (46) & retrospective & 52 & Children & mandible (62) & $12-14(50)$ \\
\hline Oji (16) & retrospective & 900 & total & mandible (53) & $21-30(36)$ \\
\hline Olasoji (53) & retrospective & 105 & total & mandible (43) & $20-29(42)$ \\
\hline Ugboko et al (42) & retrospective & 22 & total & Zygoma (27) & $21-40$ \\
\hline Fasola et al (28) & retrospective & 77 & total & mandible (54.4) & $21-30(52)$ \\
\hline Fasola et al (30) & retrospective & 831 & total & \# & $21-30(33)$ \\
\hline Fasola et al (19) & prospective & 103 & total & $\#$ & $21-30(47)$ \\
\hline Fasola et al (25) & retrospective & 93 & children & mandible (86) & $11-16(54)$ \\
\hline Fasola et al (26) & retrospective & 72 & children & \# & $12-16(57)$ \\
\hline Olasoji et al (4) & prospective & 306 & total & mandible (66) & $2 I-30(4 I)$ \\
\hline Olasoji et al (54) & retrospective & 102 & Children & mandible (73) & $12-15(54)$ \\
\hline Ugboko et al (5I) & retrospective & 34 & total & mandible (56) & $11-30(74)$ \\
\hline Oginni et al (43) & retrospective & 8 & children & $\#$ & \#\# \\
\hline Oginni et al (44) & retrospective & 174 & children & \# & \#\# \\
\hline Fasola et al (29) & aretrospective & 531 & total & $\#$ & $21-30(39)$ \\
\hline Fasola et al (3I) & prospective & 76 & total & \# & $2 I-30(5 \mathrm{I})$ \\
\hline Fasola et al (18) & bpro/retrospective & 824 & total & mandible (75) & $21-30(36)$ \\
\hline Fasola et al (24) & prospective & 159 & total & mandible & $21-30(36)$ \\
\hline Fasola et al (27) & retrospective & 53 & adults & mandible (96) & 60-70 (77) \\
\hline Saheeb et al (56) & retrospective & 250 & total & mandible (65) & $20-30(32)$ \\
\hline Adebayo et al (50) & retrospective & 443 & total & mandible (64) & $20-39(65)$ \\
\hline Bankole et al (35) & retrospective & 64 & children & $\#$ & $0-5$ \\
\hline Ugboko et al (45) & retrospective & 128 & total & \# & $21-30(38)$ \\
\hline
\end{tabular}

a analysis of concomitant injuries in patients with maxillofacial fractures

bcomparative study

total $=$ all age groups

\# = not applicable

\#\# not specified

Most of the studies lack uniformity and consistency in assessment and measurement variables (information bias) and treatment modalities. The age bracket of patients considered as "children" by several investigators varied considerably (Fasola et al [26], 16 years and below; Oji [55], under 11 years; Olasoji, under 15 years; Ugboko et al, 14 years and below [46]; Denloye et al [33], less than 17 years; Oginni et al [44], 15 years and below). Repetition of the same data in different studies was also observed. While most of the published articles focused only on hard tissue injuries, few others reported on either hard and soft tissue injuries or soft tissue only (Table 1). 
Table 3: Analysis of road traffic injuries due to motor vehicles and motorcycles between I965 and I999 in Ibadan and between 1985 and 1995 in Enugub.

IBADAN (South-west, Nigeria)

\begin{tabular}{lcccc}
\hline $\begin{array}{l}\text { Types of automobile } \\
\text { involved }\end{array}$ & \multicolumn{3}{c}{ Study period } \\
\hline & $1965-1975$ & $1978-1982$ & $1982-1984$ & $1995-1999$ \\
\hline Motor vehicles & $46.3 \%$ & $84.9 \%$ & $80 \%$ & $63.4 \%$ \\
Motorcycles & $7.8 \%$ & $10.6 \%$ & $\#$ & $20.6 \% *$ \\
& & ENUGU (South-east, Nigeria) \\
\hline
\end{tabular}

\begin{tabular}{|c|c|c|}
\hline & \multicolumn{2}{|c|}{ Study period } \\
\hline & $1985-1990$ & $199 \mid-1995$ \\
\hline Motor vehicles & $59 \%$ & $59 \%$ \\
\hline Motorcycles & $16 \%$ & $25 \%$ \\
\hline
\end{tabular}

a adapted from Abiose [22], Ajagbe et al [2I], Fasola et al [18] and Nyako [23]

b adapted from Oji [16]

$\#=$ not specified

* statistically significant $(p=0.02)$

Although, the majority of the patients in the studies were treated by closed reduction and fixation methods, uniformity in treatment was lacking. Due to the heterogeneity of the study methodologies in this review it was not possible to apply the traditional methods of a systematic review. A meta-analysis is only suitable if there is sufficient similarity in the populations studied and the measurements used. This was not the case with the studies identified in this review. Therefore, a narrative approach was taken to report the findings of the included studies.

Data was analysed using the SPSS for window (version 11.5; SPSS Inc, Chicago, IL) statistical software package. Descriptive statistics and the non-parametric chi square test were used to analyse the incidence of injuries in different time periods. The critical level of significance was set at $\mathrm{p}<.05$.

\section{Results}

Of the 42 articles reviewed, 31 were retrospective studies, 9 prospective, 1 article was a case report and 1 article was a comparative study of a prospective and a retrospective data. Road traffic crash (RTC) was the major cause of maxillofacial injuries in both children and adults in all the zones of the country with the exception of north eastern states where assault was the major cause of injuries (Table 1). Although, motor vehicles were responsible for most cases of RTC, motorcycle related injuries increased significantly between 1965 and 2003. Between 1965 and 1999 in Ibadan, the number of motorcycle-related maxillofacial injuries increased by a factor of 2.6, and more significant cases $(p=.02)$ of motorcycle related injuries were recorded in 1978-1982 period compared to 1995-1999 (Table 3). In Enugu (SE) Nigeria, between 1985 and 1995, the number of motorcycle related maxillofacial injuries increased by a factor of 1.6 (Table 3 ). An increase in the number of motorcycle related maxillofacial injuries was also observed between 1973 and 2000, and between 1976 and 1995 in Kaduna (NC) [48,51] and Ife (SW) [1,41] respectively. In Benin (SS) [56] and Lagos (SW) [37], $26.5 \%$ and $19.0 \%$ of cases with maxillofacial injuries were involved in motorcycle related crashes respectively, and motorcycle passengers sustained more severe injuries than other vehicle users $[37,56]$.

Pedestrian related maxillofacial fractures also increased in major cities across the country. In Ibadan (SW), an increase by a factor of 3.2 was reported between 1978 and 1999 [18,23] and in Lagos (SW), 35.6\% (1983-1986) and $28.1 \%(1989-1992)$ of patients involved in RTC were pedestrians hit by vehicles $[37,38]$.

Assaults were the second most common cause of injuries in most centres followed by falls (Table 1). Falls were important causes of injuries in children. Increase in the number of patients who sustained injuries as a result of assaults, falls, sports injuries and industrial accidents was observed in most centers over the years 
$[1,18,35,37,46,48,51,53]$. Animal attacks were also a frequent cause of maxillofacial injuries especially in northern part of the country $[4,43,45,52]$.

The peak age of incidence of maxillofacial injuries was 21-30 years in most centers followed by 31-40 years. In children, injuries occurred mostly in children aged $>10$ years. More males were affected than females in all age groups. A tendency towards an equal male-to-female ratio was observed between earlier and later studies in most urban centers. A significant reduction in male-to-female ratio from 16.9:1 (1973-1978) to 3:1 (1991-2000) was reported from Kaduna (NC) (Table 1). Another significant reduction in male-to-female ratio from 6.4:1 (19781982) to 3.3:1 (1995-1999) was reported from Ibadan (SW) (Table 1).

The Mandible was the most frequently involved bone in maxillofacial fractures in all the centers across the country, and the most frequently involved middle-third bone was the zygoma $[1,18,22,32,50]$. The LeFort I fracture was the most common of the LeFort fracture types $[1,4,22]$. Analysis of fracture of the mandible revealed mandibular body as the most frequently involved part, followed by symphyseal/ parasymphyseal region $[1,4,18,23,25,37$ $39,46,47,50]$. Dentoalveolar and condylar fractures were less frequently reported. Another remarkable feature of maxillofacial injuries in most reports was extensive soft tissue injuries $[30,18,37,38,56]$.

Closed reduction and dental wiring with arch bars, direct wires and eyelet wires combine with intermaxillary fixation were the most common form of treatment $[1,21,34,47,50]$ for mandibular fractures. Wire osteosynthesis is employed for open reduction and internal fixation of mandibular fractures in few cases $[1,21,22,50]$. Fractures of the maxillae/LeFort fractures were reduced and fixed by eyelets/arch bars combined with suspension wires and intermaxillary fixation $[1,32,34,47,50]$. Zygomatic complex fractures were treated either conservatively or by either closed or open reduction with Gillies' temporal approach, lateral coronoid approach or transosseous wiring $[21,42,45,47]$.

\section{Discussion}

The large variations in assessment and measurement variables, as well repetition of data employed by previous investigators of maxillofacial injuries in Nigeria made a systematic review impossible. However, analysis of the previous studies on maxillofacial injuries in Nigeria showed a noticeable trend and characteristic.

Although, road traffic crashes remained the major etiological factor of maxillofacial injuries other causes like assaults, sport injuries and industrial accidents have increased in numbers between 1965 and 2003 in Nigeria. This finding is in agreement with reports from other developing countries where RTC remains the major etiologic factor of maxillofacial injuries $[12,13,17]$, but contrasts reports from developed countries where assaults and interpersonal violence has replaced RTC as the major cause of maxillofacial injuries $[6,10,11,18]$. Civilian-type maxillofacial injuries were rare prior to Nigerian independence in 1960 [21]. Immediate post independence period witnessed a significant increase in the numbers of motor vehicles imported into the country. It is worthwhile to note that the period from 1965 up to the present time has witnessed a steady increase in the number of secondhand vehicles into Nigeria. Also, lack of enforcement of reshipment inspection rules and regulations has encouraged the importation of vehicles whose road worthiness leaves much to be desired [1]. In addition, the roads are badly maintained, and there is general lack of enforcement of traffic rules and regulations, especially the use of seat belts. Non-usage of protective elements was also thought to be responsible for extensive soft tissue injuries seen in maxillofacial injured patients $[18,37,38,56]$.

Over the last 40 years, there has been a significant increase in the number of maxillofacial injuries that resulted from motorcycle accidents in Nigeria (Table 3 ). These findings contrast that of others [57] who reported a decrease in the number of motorcyclists involved in maxillofacial injuries. However, Konto et al [58] reported that bicycle related maxillofacial fractures increased by $19.3 \%$ between 1981 and 1997 in Finland. The increase in the present study is due to a significant increase in the number of motorcycles plying Nigeria roads. Even in Abuja, the nation's capital, anecdotal evidence has shown that motorcyclists and their passengers are involved in more than $55 \%$ of cases of road traffic crashes. In the United States of America (USA), the number of registered motorcycles increased from 600,000 units in 1961 to 3.3 million units in 1971; a $450 \%$ increase within a decade $[59,60]$. This pattern was also recognised in Nigeria when the number increased from 144,480 units to 284,124 units between 1976 and 1981, an increase of almost $200 \%$ within 5 years [61]. Motorcycles have become a prominent mode of transportation in both urban and suburban cities in Nigeria. Frequent traffic jams as a result of poor road network in the country have made motorcycles attractive to commuters because motorcycles can pass through narrow ways [18]. However, most of the motorcyclists are unlicensed and often do not follow traffic rules and regulation. Fasola et al [24] reported that only one $(3.8 \%)$ of the motorcyclists who sustained maxillofacial injuries within Ibadan city (SW) wore a crash helmet while Saheeb and Etetafia [56] reported that none of the motorcyclists and their passengers involved in RTC in Benin city (SS) wore protective helmet. 
The number of pedestrians involved in maxillofacial injuries has also been on the increase especially in urban centres unlike reported elsewhere [57]. This is peculiar to the overpopulated cities with few subways and overhead bridges. Therefore, it is relatively common for pedestrians to have to run in oncoming vehicular traffic $[18,38]$. Konto et al [58] also reported an increase in pedestrian related maxillofacial fractures in their study.

While RTC have been steadily falling in the developed countries, they continue to rise with horrifying speed in the low and middle-income (LMIC) countries of Africa and Asia [62]. The World Health Organisation (WHO) has estimated that nearly $25 \%$ of all injury fatalities worldwide are a result of road traffic crashes, with $90 \%$ of the fatalities occurring in LMIC [62]. The reductions in RTC in developed countries are largely attributed to a wide range of road safety measures such as seat belt use, traffic calming measures and traffic law enforcement. Therefore, there is an urgent need to get down to what the developed nations have done to reduce/prevent road traffic crashes.

Assaults and falls were the second most common cause of maxillofacial injuries in adults and children respectively in all centres except the north eastern part of the country, where assaults remained a major cause (Table II). Other common causes were sport injuries, industrial accidents and animal attacks. Fasola et al [18] in Ibadan (SW) reported an increase in number of maxillofacial injuries due to assaults, falls, sporting injuries and industrial accidents between 1978 and 1999 by a factor of 1.4, 1.5, 3.5, and 1.5 respectively. Increase in number of assaults related maxillofacial injuries could be attributed to the poor socioeconomic conditions of the country leading to stress and propensity to crime. In fact, the employment rate among college and university graduates has increased from $4 \%$ during the early 1970 s to $45 \%$ currently [4]. Furthermore, the poor capital income of an average Nigerian has decreased by $75 \%$ during the past $20-25$ years $[4,63]$. The prevalence of assaults related injury in north eastern Nigeria could be attributed to nomadic form of life style in this region, where animals are moved over several kilometres of land grazing without strict laws guiding their movement thereby destroying cash crops [53]. This frequently led to fights between farmers and cattle men, and various objects such as cutlasses/machetes, arrows and wooden objects are used in inflicting injuries during fight $[4,53]$. This is unlike European and American studies where most of the fights occurred in the streets, clubs and pubs $[6,7,10,11]$.

Also, the increase in maxillofacial injuries due to sports injuries and industrial accidents could be attributed to increase involvement of Nigerians in recreational and pro- fessional sport activities, and increase in the numbers of industries over the years without corresponding increase in protective measures. Onyeaso and Adegbesan [64] in a survey among Nigerian sport persons reported that only one-third of them ever used protective elements during sporting activities, whereas about $60 \%$ of them have had one form of orofacial injury or the other before.

Maxillofacial skeletal and soft injuries due to animal attacks were not infrequent, especially in northern part of the country $[4,51,52]$. While dogs remain the animals most commonly implicated in other reports $[65,66]$, cows, camels and donkeys were mostly involved in Nigeria, because cattle rearing and use of animals as "beasts of burden" are still prevalent practices in northern part of Nigeria $[4,51,52]$.

The peak age of incidence of maxillofacial injuries of 2130 years among Nigerians is not different from reports from other parts of the world [5-10,12-14,57]. The possible explanation for this is that people in this age group take part in dangerous exercises and sports, drive motor vehicles carelessly, and are most likely to be involved in violence [16].

More males were involved in maxillofacial injuries than females in agreement with previous reports [5-10,13,14]. However, a tendency towards an equal male-to female ratio was observed between earlier and later studies in most centres across the country. This can be attributed to a changing workforce. Women, who are used to stay at home, now work in outdoor and high-risk occupations, thus becoming exposed to RTC and other causes of maxillofacial injuries $[18,50]$.

Most of the fractures of maxillofacial skeleton in Nigerian patients were of the mandible, the findings comparable to other reports $[9,12-14]$. The mobility of the mandible and the fact that it has less bony support than the maxilla have been implicated $[16,67]$. Dentoalveolar and condylar fractures were reported to be less in Nigerian patients $[1,9,12-14,54]$. Dental/dentoalveolar injury is frequently overlooked in surveys that review maxillofacial injury [68$70]$. Only the analysis of a large number of injuries reveals the risk of suffering from dentoalveolar trauma [68-70]. Gassner et al [69] in a large series of 9,543 patients with 21,067 maxillofacial injuries reported an incidence of $49.9 \%$ of dentoalveolar injuries among their patients. Gassner et al [70] in another large series of craniomaxillofacial trauma in 3,385 children younger than 15 years of age reported an incidence of $76.3 \%$ cases of dentoalveolar injuries. Midfacial bone fractures especially LeFort types and orbital floor fractures were reported to be commoner than mandibular fractures $[69,70]$ in contrast to Nigerian reports. A low utilization of technological advances in the 
imaging of maxillofacial fractures (e.g. CT Scan) in Nigeria may be partially responsible for the observed difference. The midfacial skeleton is much more difficult to assess using plain films than is the mandible [71]. The presence of thin bones, fluid-filled spaces (e.g. congested sinuses), and soft tissues (e.g. orbital contents) make accurate assessment difficult with images that do not offer a high degree of contrast [71]. The difference in the incidence of middle-third fractures has also been related to the refusal of Nigerian motorists to use safety devices, which has reduced their survival after severe middle-third fractures [50].

Although, open reduction and internal fixation remains the "gold standard" of treatment of maxillofacial fractures $[72,73]$, this form of treatment however, has not become popular in our environment [1,50]. Presently, the full compliment of equipment and materials for rigid fixation is not readily available in all parts of the country; and where available, the cost of treatment is usually quite prohibitive [45]. Previous Nigerian reports have, however attested to the satisfactory results obtained using simple conservative methods of closed reduction and mandibulo-maxillary fixation $[1,4,16,19,21,25,32,36,45,50,54]$.

\section{Conclusion}

No apparent shift from road traffic crashes as the leading cause of maxillofacial injuries in Nigeria over a period of 40 years was observed, unlike in most developed countries where assaults/interpersonal violence has replaced road traffic crashes as the major cause of the injuries. Injuries have causes, they do not simply befall us from fate or bad luck. Since no magic pill is envisaged for the prevention of road traffic crashes, we need to take good stock of all the tools at our disposal, and to get down to what the developed nations have done to reduce/prevent road traffic crashes. Therefore, an awareness campaign to educate the public about the importance of restraints and protective headgear in cars and motorcycles should be championed. These findings should also alert the authorities, particularly the government and the Road Safety Commission to the need for the provision of good roads, enforcement of existing traffic laws, and general improvement of socioeconomic condition of the populace.

\section{Competing interests}

The author(s) declare they have no competing interest.

\section{Authors' contributions}

WLA conceived the study and did the literature search, coordinated the write-up and submission of the article. WLA, ALL, MOO and OJ participated in the writing of the manuscript. All the authors read and approved the final manuscript.

\section{Acknowledgements}

The authors are grateful to the followings: Prof. J.A. Akinwande, Dr. A.O.Fasola, Prof. V.I. Ugboko, Dr. H.O. Olasoji, Dr. G.T. Arotiba and Dr. J.T. Arotiba, for their assistance during the preparation of this manuscript.

\section{References}

I. Ugboko VI, Odusanya SA, Fagade OO: Maxillofacial fractures in a semi- urban Nigerian teaching hospital. A review of 442 cases. Int J Oral Maxillofac Surg 1998, 27:286-289.

2. Kihlbert JK: Head injury in automobile accidents. Automobile Injury Research Report 1965. No VJ-I823-RI7.

3. Nahum AM, Siegel AW, Brooks S: The reduction of collision injuries. Past, present and future. In Proc 14th STAPP Car Conference New York: Society of Automobile Engineers; 1970:1-43.

4. Olasoji HO, Tahir A, Arotiba GT: Changing picture of facial fractures in northern Nigeria. Br J Oral Maxillofac Surg 2002, 40:140-143.

5. Khan AA: A retrospective study of injuries to the maxillofacial skeleton in Harare, Zimbabwe. Br J Oral Maxillofac Surg 1988, 26:435-439.

6. Magennis P, Shepherd J, Hutchison I, Brown A: Trends in facial injuries: increasing violence more than compensate for decreasing road trauma. BMJ 1998, 3 16:325-332.

7. Van Hoof RF, Mrérlex CA, Stekelenberg EC: The different pattens of fractures of the facial skeleton in four european countries. Int J Oral Surg 1977, 6:3-II.

8. Afzeilus LE, Rosen C: Facial fractures: A review of 368 cases. Int J Oral Surg 1980, 9:25-33.

9. Brown RD, Cowpe JG: Patterns of maxillofacial trauma in two different cultures. J R Coll Surg Edinb 1985, 30:299-302.

10. King RE, Scianna JM, Petruzzelli GJ: Mandible fracture patterns: a suburban trauma center experience. Am J Otolaryngol 2004, 25:30I-307.

II. Laski R, Ziccardi VB, Broder HL, Janal M: Facial trauma: a recurrent disease? The potential role of disease prevention. J Oral Maxillofac Surg 2004, 62:685-688.

12. Ansari MH: Maxillofacial fractures in Hamedan province, Iran: a retrospective study (1987-200I). J Craniomaxillofac Surg 2004, 32:28-34.

13. Al Ahmed HE, Jaber MA, Abu Fana SH, Karas M: The pattern of maxillofacial fractures in Sharjah, United Arab Emirates: a review of 230 cases. Oral Surg Oral Med Oral Pathol Oral Radiol Endod 2004, 98:166-170.

14. Erol B, Tanrikulu R, Gorgun B: Maxillofacial fractures: Analysis of demographic distribution and treatment in $290 \mathrm{I}$ pateints (25-year expereience). J Craniomaxillofac Surg 2004, 32:308-313.

15. Oji C: Maxillofacial injuries. Plast Reconstr Surg 1996, 97:866-868.

16. Oji C: Jaw fractures in Enugu, Nigeria, 1985-1995. Br J Oral Maxillofac Surg 1999, 37:106-109.

17. Nwoku AL, Oluyadi BA: Retrospective analysis of I 206 maxillofacial fractures in an urban Saudi hospital: 8 year review. Pakistan Oral Dent J 2004, 24:13-16.

18. Fasola AO, Nyako EA, Obiechina AE, Arotiba JT: Trends in the Characteristics of Maxillofacial Fractures in Nigeria. J Oral Maxillofac Surg 2003, 61: I |40-I | 43 .

19. Fasola $A O$, Obiechina $A E$, Arotiba JT: An audit of midfacial fractures in Ibadan, Nigeria. Afr J Med Med Sci 200I, 30:183-186.

20. Telfer MR, Jones GM, Shepherd JP: Trends in the aetiology of maxillofacial fracture in the United Kingdom (1977-1987). BrJ Oral Maxillofacial Surg 199|, 29:250-255.

21. Ajagbe HA, Daramola JO, Oluwasanmi JO: Civilian-type facial injuries- A retrospective study of cases seen at the University College Hospital, Ibadan. Nigerian Med J 1977, 7:432-436.

22. Abiose $B O$ : Maxillofacial skeleton injuries in the Western states of Nigeria. Br J Oral Maxillofac Surg 1986, 24:3 I-39.

23. Nyako AE: Review of facial fractures at the University College Hospital Ibadan (1 978-1 982). Thesis, West African Postgraduate Medical College, Lagos, Nigeria; 1985.

24. Fasola $A O$, Lawoyin JO, Obiechina AE, Arotiba JT: Inner city maxillofacial fractures due to road traffic accidents. Dent Traumatol 2003, 19:2-5.

25. Fasola AO, Denloye OO, Obiechina AE, Arotiba JT: Facial bone fractures in Nigerian children. Afr J Med Med Sci 200I, 30:67-70.

26. Fasola $A O$, Obiechina $A E$, Arotiba JT: Fractures of the mandible in children. East Afr Med J 200 I, 78:6I-3. 
27. Fasola $A O$, Obiechina $A E$, Arotiba $J T$ : Incidence and pattern of maxillofacial fractures in the elderly. Int J Oral Maxillofac Surg 2003, 32:206-208.

28. Fasola $\mathrm{AO}$, Obiechina $\mathrm{AE}$, Arotiba JT: Sports related maxillofacial fractures in 77 Nigerian patients. Afr J Med Med Sci 2000, 29:215-217.

29. Fasola $\mathrm{AO}$, Obiechina $\mathrm{AE}$, Arotiba JT: Concomitant injuries in $53 \mathrm{I}$ patients with maxillofacial fractures. Afr J Med Med Sci 2002, 31:101-105.

30. Fasola $A O$, Obiechina $A E$, Arotiba JT: Soft tissue injuries of the face: a 10 year review. Afr J Med Med Sci 2000, 29:59-62.

31. Fasola AO, Obiechina AE, Arotiba JT: Zygomatic complex fractures at the University College Hospital, Ibadan, Nigeria. East Afr Med J 2002, 79:137-139.

32. Abiose $\mathrm{BO}$ : The incidence and management of middle third facial fractures at the University Teaching Hospital, Ibadan. East Afr Med J 1991, 68:164-I73.

33. Denloye OO, Fasola AO, Arotiba JT: Dental emergencies in children seen at University College Hospital (UCH), Ibadan, Nigeria- 5 year review. Afr J Med Med Sci 1998, 27:197-199.

34. Ajagbe HA, Daramola JO: Pattern of facial bone fractures seen at the University Teaching Hospital, Ibadan, Nigeria. East African Med J 1 980, 57:267-273.

35. Bankole OO, Fasola AO, Denloye OO: Oro-facial soft tissue injuries in Nigerian children: a five-year review. Afr J Med Med Sci 2004, 33:93-97.

36. Nwoku AL, Akinosi JO, Solarin EO, Obisesan BA: Results of outpatient treatment of mandibulo-maxillary fractures in LUTH. Niger Med J 1979, 9:100-106.

37. Akinwande JA: Fracture of the mandible due to road traffic accidents in Lagos, Nigeria. Nig Dent J 1990, 9:15-22.

38. Arotiba GT: Facial fractures due to road traffic accidents in Lagos. Niger Med J 1996, 30:66-69.

39. Arotiba GT: The aetiology of facial fractures in Lagos. Niger Postgrad Med J 1996, 3:37-42.

40. Akinwande JA, Ogunbanjo B, Ladeinde A, Ogunlewe O, Obisesan B, Oluseye T: Armed robbery gunshot injuries to the maxillofacial region. Journal clinical Practice 1998, I:9-I4.

41. Odusanya SA: Maxillofacial fractures in South Western Nigeria (1976-198I). Odontostomatologie Tropicale 1985, 3:153-156.

42. Ugboko VI, Owotade FJ, Oginni FO, Odusanya SA: Gunshot injuries of the orofacial region in Nigerian civilians. SADJ 1999, 54:418-422.

43. Oginni FO, Akinwande JA, Fagade OO, Arole GF, Odusanya SA: Facial dog bites in Southwestern Nigerian children. An analysis of eight cases. Trop Doc 2002, 32:239-240.

44. Oginni FO, Fagade OO, Akinwande JA, Arole GF, Odusanya SA: Pattern of soft tissue injuries to the oro-facial region in Nigerian children attending a teaching hospital. Int J Paediatr Dent 2002 12:201-206.

45. Ugboko V, Udoye C, Ndukwe K, Amole A, Aregbesola S: Zygomatic complex fractures in a suburban Nigerian Population. Dent Traumatol 2005, 2 I:70-75.

46. Ugboko V, Odusanya S, Ogunbodede E: Maxillofacial fractures in children: An analysis of 52 Nigerian cases. Ped Dent J 1998, 8:3I-35.

47. Adekeye EO: The pattern of fractures of the facial skeleton in Kaduna, Nigeria. A survey of I,447 cases. Oral Surg 1980, 6:491-495

48. Adekeye EO: Fractures of the zygomatic complex in Nigerian patients. J Oral Surg 1980, 38:596-9.

49. Adekeye EO: Pediatric fractures of the facial skeleton: a survey of 85 cases from Kaduna, Nigeria. J Oral Surg 1980, 38:355-358

50. Adebayo ET, Ajike OS, Adekeye EO: Analysis of the pattern of maxillofacial fractures in Kaduna, Nigeria. Br J Oral Maxillofac Surg 2003, 41:396-400.

5I. Ugboko VI, Olasoji HO, Ajike SO, Amole AOD, Ogundipe OT: Facial injuries caused by animals in northern Nigeria. $\mathrm{Br}$ J Oral Maxillofac Surg 2002, 40:433-437.

52. Ogunbodede EO, Arotiba JT: Camel bite injuries of the orofacial region: report of a case. J Oral Maxillofac Surg 1997, 55: I I74- I I 76.

53. Olasoji HO: Maxillofacial injuries due to assault in Maiduguri, Nigeria. Trop Doc 1999, 29:106-108.
54. Olasoji HO, Tahir A, Bukar A: Jaw fractures in Nigerian children: an analysis of 102 cases. Cent Afr J Med 2002, 48: I09-II 2.

55. Oji C: Fractures of the facial skeleton in children: a survey of patients under the age of I I years. J Craniomaxillofac Surg 1998, 26:322-325

56. Saheeb BDO, Etetafia MO: Influence of positions on the incidence and severity of maxillofacial injuries in vehicular crashes. West Afr J Med 2003, 22:|46-| 49.

57. van Beek GJ, Merkx CA: Changes in the pattern of fractures of the maxillofacial skeleton. Int J Oral Maxillofac Surg 1999, 28:424-428.

58. Kontio R, Suuronen R, Ponkkonen H, Lindqvist C, Laine P: Have the causes of maxillofacial fractures changed over the last 16 years in Finland? An epidemiological study of $\mathbf{7 2 5}$ fractures. Dent Traumatol 2005, 21:14-19.

59. Kraus JF, Riggins RS, Franti CE: Some epidemiological features of motorcycle collision injuries. Am J Epid 1975, 102:74- II3.

60. Deaner RM, Fitchett VH: Motorcycle trauma. I Trauma I975, I 5:678-68|.

61. Adegbehingbe BO, Oluwadiya KS, Adegbehingbe OO: Motorcycle associated ocular injuries in Ile-Ife, Nigeria. African Journal of Trauma 2004, 2:35-39.

62. Kobusingye OC: Why poor countries cannot afford to ignore road safety. African Journal of Trauma 2004, 2:6.

63. Robinson S: Hope for Nigeria. Newsweek International 1999, 7:23.

64. Onyeaso $\mathrm{CO}$, Adegbesan OA: Orofacial injury and mouthguard usage by athletes in Nigeria. Int Dent J 2003, 53:23 I-236.

65. Wolff KD: Management of animal bite injuries of the face: expereience with 94 patients. J Oral Maxillofacial Surg 1998, 56:838-843

66. Fourie L, Cartilidge D: Fracture of the maxilla following dog bite to the face. Injury 1995, 26:61-62.

67. Kelly DE, Harrigan WE: A survey of facial fractures: Bellevue Hospital, 1948-1974. J Oral Surg |975, 33:|46-|49.

68. Tuli T, Hachl O, Rasse M, Kloss F, Gassner R: Dentoalveolar trauma analysis of 4763 patients with 6237 injuries in 10 years. Mund Kiefer Gesichtschir 2005, July 2:.

69. Gassner R, Tuli T, Hachl O, Rudisch A, Ulmer H: Cranio-maxillofacial trauma: a 10 year review of 9,543 cases with 21,067 injuries. J Craniomaxillofac Surg 2003, 3 I:5I-6I.

70. Gassner R, Tuli T, Hachl O, Moreira R, Ulmer H: Craniomaxillofacial trauma in children: a review of 3,385 cases with 6,060 injuries in 10 years. J Oral Maxillofac Surg 2004, 62:399-407.

7I. Ellis $E$ 3rd, Scott K: Assessment of patients with facial fractures. Emerg Med Clin North Am 2000, 18:4 I I-448.

72. Aziz SR, Ziccardi VB, Borah G: Current therapy: complications associated with rigid internal fixation of facial fractures. Compend Contin Educ Dent 2005, 26:565-57I.

73. Van Sickels JE: A review and update of new methods for immobilisation of the mandible. Oral Surg Oral Med Oral Pathol Ora Radiol Endod 2005, 100:SII-SI6.

Publish with Bio Med Central and every scientist can read your work free of charge

"BioMed Central will be the most significant development for disseminating the results of biomedical research in our lifetime. "

Sir Paul Nurse, Cancer Research UK

Your research papers will be:

- available free of charge to the entire biomedical community

- peer reviewed and published immediately upon acceptance

- cited in PubMed and archived on PubMed Central

- yours - you keep the copyright
BiolMedcentral 